\title{
Pohjoismaiden kulttuurit, historiat ja yhteiskunnat pohjoisamerikkalaisittain
}

\author{
Scandinavian Studies Conference. Annual Meeting - Society for the \\ Advancement of Scandinavian Study (SASS), 3.-5.5.2018, UCLA, Los Angeles.
}

\author{
Kati Mikkola ja Eija Stark
}

$\mathrm{V}$ uotuinen Pohjois-Amerikan Skandinavian tutkimuksen konferenssi (SASS) järjestettiin tänä vuonna Los Angelesissa, Yhdysvaltojen länsirannikon maineikkaassa Kalifornian yliopistossa, UCLA:ssa. Rajaavasta Skandinavia-nimestään huolimatta konferenssi kokoaa yhteen kaikkia Pohjoismaita koskevaa humanistista ja yhteiskuntatieteellistä tutkimusta. Joka vuosi järjestettävä konferenssi on tärkeä osoitus sikäläisten Pohjoismaiden tutkijoiden halusta ylläpitää tieteellistä yhteistyötä aihealueella, joka on varsin marginaalinen Yhdysvaltojen akateemisessa tutkimuskentässä. Jason Laveryn, Oklahoman valtionyliopiston historian professorin mukaan kuvaavaa on se, että esimerkiksi historian oppiaineessa kaikki Pohjoismaiden historiaan liittyvä tutkimus ja opetus on sisällytettävä Euroopan historian tutkimuksen ja -opetuksen alaisuuteen. Tässä kontekstissa Suomi ja muut Pohjoismaat väistämättä jäävät vähäiseen rooliin Venäjän ja Ranskan vallankumousten, reformaation, natsi-Saksan ynnä muiden "suurten historia-aiheiden" rinnalla. $\mathrm{Ne}$, jotka päätyvät tekemään graduaan tai väitöstyötään Pohjoismaista, ovat omaehtoisesti hakeutuneet spesifin aiheensa pariin.

Tämän vuoden konferenssissa osanottajia oli noin 200, joista yli puolet oli Pohjoismaista ja Keski-Euroopan yliopistoista tai tutkimusinstituuteista. Kun ottaa huomioon, että myös yhdysvaltalaisten yliopistojen osanottajista merkittävä osuus on Pohjoismaiden kansalaisia tai täältä lähtöisin, Yhdysvalloissa peruskoulutuksen saaneet ovat SASSissa vähemmistönä. Yhtä kaikki, vuotuinen konferenssi on heille iloksi siitäkin syystä, ettei heidän tällöin tarvitse matkustaa Eurooppaan saadakseen asiantuntevaa ja kiinnostunutta yleisöä omalle tutkimukselleen.

\section{Tulevaisuus on pimeä - mutta ei se haittaa}

SASSin konferenssiprofilissa esitelmät ovat kiinnittyneet kolmeen vahvaan tutkimusalaan: kirjallisuuteen, historiaan ja perinteentutkimukseen. Konferenssissa pääpuhujat eivät ole tutkijoita, vaan tehtävä on annettu joka vuosi jollekin pohjoismaiselle taiteentekijälle. Tänä 
vuonna pääesitelmän piti tanskalainen kirjailija Carsten Jensen, joka tunnetaan myös aktiivisena yhteiskunnallisena keskustelijana. Jensen on pohtinut teoksissaan muun muassa nykyaikaista sodankäyntiä ja poliittista populismia.

Esitelmässään Jensen pohti omakohtaisin esimerkein dilemmaa optimismin ja pessimismin välillä nykymaailmassa, jossa asioiden ennustettavuus tuntuu vähentyneen. Jugoslavian sodan näkeminen teki Jensenistä pessimistin, mutta kun hän tämän jälkeen kiersi vuoden maailmaa, palasi hän Eurooppaan takaisin optimistina. Jensen näki maita, jotka olivat selviytyneet monenlaisista kauheuksista ja koki itse saaneensa ihmisiltä apua aina kun sitä tarvitsi. Jensen tiivisti tulevaisuusnäkynsä tulkintaan siitä, että vaikka tulevaisuus näyttää pimeältä, se merkitsee ainoastaan sitä, että tulevaisuus on tuntematon. Pimeään emme näe. Tämä puolestaan on kutsu toimintaan, ei pessimistiseen toimimattomuuteen.

Jensen pohti esitelmässään kiinnostavasti sitä, miten ihminen voi löytää identiteettinsä joko asioista, jotka erottavat hänet muista tai asioista, jotka yhdistävät hänet muihin ihmisiin. Myös kansakunnan historiallinen muisti ja sen varaan rakennettu identiteetti sisältävät valintoja. Jensen otti esimerkiksi kotimaansa Tanskan: kansallisen omakuvan kannalta on iso ero siinä, korostetaanko esi-isien olleen maanviljelijöitä vai merimiehiä - siis rakentuuko tanskalaisuus agraarin menneisyyden varaan vai ajatukselle siitä, että kotimaa on ollut pieni valtio, joka merenkulun kautta tunsi kaikki mantereet ja oli yhteydessä kaikkialle maailmaan. Jensenin oma lapsuuden kasvuympäristö oli merimiesyhteisö, jossa yhdistyivät kotiseudun paikallinen identiteetti ja kosmopoliittisuus. Ympärillä oli ihmisiä, jotka tunsivat Kongon joet siinä missä lähiseudun vesireititkin.

\section{Saamelaisuuden representaatioista geenitesteihin}

Konferenssin folkloristiikan ja etnologian alaan lukeutuneet esitelmät liittyivät etupäässä kansakunta-käsitteen syntymekanismeihin, kansanomaisen kulttuurin ideologisiin ulottuvuuksiin, muistelukerronnan tapoihin sekä islantilaiseen tarinaperinteeseen ja sen digitalisaatiohaasteisiin. Myös saamelaisuus oli konferenssissa näkyvästi esillä, tällä kertaa erityisesti yhdysvaltalaistutkijoiden voimin. Otsikon "Saamelaisuus" paneelissa oli neljä esitelmää, jotka keskittyivät saamelaisuuden kulttuuristen representaatioiden muuttumiseen kuluneen sadan vuoden aikana. Esimerkiksi Tom DuBois'n aineistona olivat elokuvat ja Robert P. Wheelersburgilla aikakauslehdet ja populaarikirjallisuus. Kiinnostavinta suomalaisille on kuunnella tällaisia esityksiä siitä näkökulmasta, miten saamelaisuus näyttäytyy ei-eurooppalaisesta näkökulmasta. Esitelmien perusteella varsin kohosteiselta, toisin sanoen saamelaisuus näyttäytyy sellaisena etnisyytenä, jossa ei ole länsimaisen valtavirtakulttuurin piirteitä.

Saamelaisuus-paneelin loppukeskustelu oli vireää ja moniulotteista, päätyen lopulta jopa pohdintoihin etnisyyden geneettisistä aspekteista. Yleisöstä kysyttiin, kenet määritellään saamelaiseksi, kuka voi sanoa olevansa saamelainen ja pystyisikö sen testaamaan DNA-testeillä. Paneelin osallistujat kiistivät etnisyyden ja genetiikan yhteyden - tietenkin - vaikka osa myönsi myös itse teettäneensä DNA-analyysin omasta geeniperimästään. Keskustelu osoitti jälleen kerran sen, että ihmisillä näyttää olevan halu tietää geeniperimänsä, ja että jonkinlaisessa intuitiivisessa ajattelussa etnisyys edelleen mielletään genetiikkaan liittyväksi, vaikkei geeniperimällä ajatellakaan olevan mitään suoraa yhteyttä omaan identiteettiin. 


\title{
Valkoisen paratiisin harha
}

Suomalaisesta perspektiivistä konferenssin havahduttavin keskustelunaihe oli Pohjoismaiden tutkimuksen maine suhteessa rotukysymyksiin ja "valkoiseen ylivaltaan". Aiheeseen liittyvässä pyöreänpöydän keskustelussa yhdysvaltalaisissa yliopistoissa opettavat tutkijat pohtivat omaa rooliaan ja vastuutaan tilanteissa, joissa osa opiskelijoista hakeutuu Pohjoismaisen tutkimuksen ja erityisesti viikinkiteemojen pariin haaveillen niiden olevan eräänlainen "valkoinen paratiisi", jossa ei tarvitse ajatella rotukysymyksiä. Tutkijat pohtivat, miten yliopistoissa on mahdollista toimia rasismia vastaan ja miten yliopisto-opettajien tulisi reagoida esimerkiksi tilanteessa, jossa opiskelija tulee luennolle päällään t-paita, jossa lukee White supremacy. Keskustelussa kiinnitettiin huomiota myös siihen, että äärioikeistoa tutkitaan kulttuurintutkimuksen aloilla verrattain vähän, ja toisaalta siihen, miten puhe ääriliikkeistä, kuten uusnatseista ja fasisteista, peittää alleen paljon laajemman "valkoisen ylemmyyden", joka on sisäänrakennettu länsimaisten valtioiden olemukseen.

Pohjoismaissa työtään tekevien tutkijoiden osalta asetelma on monelta osin erilainen kuin Pohjois-Amerikassa. Pohjoismaissa sekä nykypäivää että menneisyyttä koskevissa tutkimuksissa on viime vuosina yhä enemmän painottunut pohjoismaisten kulttuurien moniaineksisuus, monietnisyys ja moniuskontoisuus. Tämä näkökulma oli painotetusti esillä myös omassa tuplasessiossamme, joka käsitteli suomalaisuuden idean syntyä sekä sen arkistopoliittisia seurauksia ja diskursiivisia representaatioita. Esityksissä käsiteltiin suomalaisuus -diskursseja eri vuosikymmeninä eri paikoissa ja erityisesti vähemmistöetnisyyksiemme (romanit, suomenjuutalaiset ja saamelaiset) näkökulmista. Yleisö, joka koostui pääasiassa Suomen historian ja yhteiskunnan hyvin tuntevista ei-suomalaisista tutkijoista, ihmetteli paneelin kriittistä otetta yhtenäiskansalliseen narratiiviin.

Toki on selvää, että analysoimalla kansakunnan tarinaa vähemmistöjen toimijuuden ja roolien näkökulmasta, esitykset saattavat vaikuttaa yritykseltä kiistää yhtenäiskulttuurin olemassaolo Suomessa. Esitykset pyrkivät kukin tavallaan osoittamaan, että jokaisena aikana on ollut yksilöitä ja ryhmiä, joiden kokemus ei ole sopinut vallitseviin ideaalityyppeihin. Tämänkaltainen tutkimus on omiaan havainnollistamaan myös sitä, että kansallinen menneisyys on mahdollista hahmottaa ja kertoa myös toisin kuin on totuttu.

\author{
Dosentti Kati Mikkola työskentelee Suomalaisuuden Kirjallisuuden Seuran \\ tutkimusosastolla.
}

Dosentti Eija Stark työskentelee Åbo Akademissa. 